\title{
Zakat as an Alternative Method of Economic Growth : The Muslim Community of West Bengal
}

\author{
Dr. Md. Rabiul Mallick \\ Department of History, Hijli College, Kharagpur, West Bengal, India. \\ mdrabiulmallick.hist@gmail.com
}

\begin{abstract}
Poverty is a curse in today's society. Most of the Muslim community in West Bengal is plagued by this curse. Poverty is a major obstacle to the education and social progress of the Muslim community in the district. The purpose of this article is to determine the need for Zakat as a financial measure to assess economic growth. Review the framework of Islamic economic concepts to propose alternative models aimed at serving nations. This article considers Zakat to be one of the most accurate methods of measuring economic growth, which means that when people pay Zakat, the level of economic development will be higher and vice versa. In other words, besides redistributing wealth among Muslims, there is a promise to pay Zakat to Muslims in order to reduce the gap between rich and poor in society and achieve self-reliance. This article mainly discusses the issue of self-reliance of the backward Muslim community through the grant of Zakat to assess economic growth.
\end{abstract}

Keywords: Muslim community, poverty, Zakat, economic growth, religious fundamentalism.

\section{Introduction}

The present social system is dependent on science and technology. In this context, one of the foundations of recent history is science. The Qur'an and the Hadith are the main sources of the Shariah that governs the Muslim community in many parts of the world. And this Qur'an is not only the scripture of the community; it is the provision of a full and fulfilling life. For that reason, it provides the necessary information according to the directions of all aspects and divisions of human life and the needs of the age. All the people of the Islamic world are aware of the provisions of the Qur'an and follow them. And one of these provisions is Zakat. But out of 9.13 crores people of West Bengal in India, 2 crores 48 lakhs 53 thousand Muslims follow this religious advice or provision but most of the Muslims are silent about its social or religious 
purpose. ${ }^{1}$ As a result, most of the Muslim people of West Bengal are afflicted with the curse of poverty.

In order to build a healthy society, it is possible to keep the body and mind free from the effects of natural artificiality, even if only a little bit, through the advice and rituals to be followed. That is, there are social, physical, and scientific benefits associated with each observance. But most of the Muslim community in the state is not aware of this benefit. Not only that, poverty is a burning problem of the Muslim society at present, and this poverty is the main obstacle to the education and progress of the Muslim society in West Bengal. Because the Muslim community does not know the real purpose or meaning of their observances, society is bound by a chain of superstition, conservatism, and religious orthodoxy. Due to this weakness, the influence of religious fundamentalism is affecting society more. Also recently the appearance of society is more horrible, where discrimination in the name of religion, violence, anger, greed, sin, even killing people is not reluctant. On the other hand, despite the fact that the place of women in Islam is respected, women are now disrespected. Incidents such as feticide, housewife killing, fifteen strong demands, and obstruction of girls' education, and even exploitation, oppression, and rape of women are on the rise. Despite the fact that taking interest or drinking alcohol is forbidden according to the advice of the Qur'an, it has taken the shape of cancer in today's society. In order to prevent this paralysis of society and to build a healthy society, it is essential to inform the Muslim community about the usefulness of the advice of the Qur'an and Hadith in today's society.

The indifference of the intellectual members of the Muslim community and the role of the fundamentalists in educating and educating the Muslim community about the purpose and social benefits of the religious provision is of great concern. Although religious education of the Muslim community is imparted in several public and private Madrasas under the Government of West Bengal, no education is imparted on the real purpose and social benefits of the religious rites. In this regard, the role of the government or the government's minority department, the Madrasas education department, remains in question. Above all, the indifferent mentality of the Muslim community in West Bengal is one of the reasons for their poverty. 
Through research on the social benefits of Zakat, a religious practice of the Muslim community in West Bengal, it can be said that this problem is difficult but can be solved. The government department of minority education or the Department of Minority Development needs to take the initiative to educate the public and private Madrasas of the district about the real purpose of its social and religious practices along with religious education. Awareness camps should be organized in every region to eradicate the conservatism and prejudice of the Muslim community in the district. The Muslim intellectual community and religious scholars of the district must come forward. It is only through this awareness of the Muslim people that it is possible to escape from the evil forces of fundamentalism. Not only will that, as a result of this awareness, 'Zakat' be useful in making the backward poor members of the Muslim society self-reliant.

'Zakat' is one of the rules of Islam, which is observed by the Muslim people of all countries of the world including India. On the other hand, by researching this Zakat, researchers have tried to alleviate poverty in more than one country. In his research paper 'Zakat as a Benchmark for Evaluating Economic Growth: An Alternative Method' in the International Journal of Business and Social Science, Dr. Adel Saria discusses how to make society economically self-sufficient through Zakat in Islam. In his article 'Zakat Fund-Concepts and Perspectives' in the journal Int. J. Monetary Economics and Finance, Ahmed said that it is possible to bridge the gap between the rich and the poor in society through religious rules. The paper further states that Zakat is one of the tools to alleviate poverty in society. Fuad Johri, in the journal Library Philosophy and Practice (e-journal), Muhammad Ridwan AB Aziz, in his article 'A Review on the Teachings of Zakat between 2003-2013', said that the study was conducted statistically in 2013 by Zakat. This study also looks at various variables. According to the study, economic researchers have provided significant advice and strategies for future research on Zakat as one of the ways to alleviate poverty due to the conflict over Zakat. In each of the above studies, excellent research has been done on Zakat. So far, however, there has been no focus on Zakat awareness or economic development in the Muslim community in West Bengal, which has been covered in this study. Through this study, a 5-year statistic has been presented to alleviate the poverty of the Muslim community in West Bengal. Through which it will be possible to make the Muslim society economically self-sufficient. 


\section{Analysis}

Zakat is an Arabic word and its lexical meaning is holiness, praise, growth, welfare, etc. ${ }^{2}$ Zakat is one of the five main duties of the Muslim community. According to the provisions of the Shari'ah, financial donations are a must for all wealthy Muslims. That is, from the Islamic point of view, the use of Zakat is to purify wealth. The Muslim scripture, the Qur'an, states, "Take Zakat from their wealth which will purify and purify them". 3

The importance of the Zakat system in maintaining the economic balance of human society is immense. According to Islamic law, Zakat is a way to free society from the destructive effects of capitalism by controlling the unbridled accumulation of wealth. On the other hand, through this Zakat, a society with a just and balanced economy is formed by eliminating the inequality between the rich and the poor. ${ }^{4}$ The main purpose of Islam is not to accumulate and store wealth according to the provisions of economics, but to maintain the balance of wealth in the society through its distribution. And to fulfill this purpose, the Islamic provision is 'Zakat'. This is why in Islam, Zakat has been made an 'obligatory' duty for the wealthy. ${ }^{5}$ It has been stated in several texts on Zakat, "According to the rules of Islam, Zakat applies to the specific and obligatory part of one's wealth". 6 M. A. Hamid said that in the conventional sense, "any kind of movable property is paid Zakat on it when it reaches a certain amount". ${ }^{7}$ In the case of economics, Zakat is "a kind of specific tax imposed on the rich."

According to the rules of Islam, if every wealthy Muslim owns a wealth of 87.48 grams (7.5 tolas) of gold or 612.35 grams (52.5 tolas) of silver or equal value of money, then he should give $1 / 4$ of his wealth or $2.5 \%$ as Zakat. $^{9}$ Zakat has also imposed on again cultural products. Agricultural Zakat is divided into two categories. The first is that it is mandatory to $1 \%$ of Zakat to $10 \%$ of the crop produced. The source of the crop water produced in this case is rainwater, spring water, and river or canal water. The second is, $1 \%$ of Zakat to $20 \%$ of the crop produced. In this case, the source of water is irrigation and water purchased by modern methods ${ }^{10}$.

According to the Shariah law, all Muslims of the world are taxed on the following commodities $^{11}$ 
i. Gold, silver, or ornaments made of them.

ii. Crops.

iii. The product content of the business.

iv. Saved money.

v. Mineral resources.

vi. Cattle.

According to the rules of Islam, the names of the things are following upon which Zakat is not imposed ${ }^{12}$.

i. Non-farming land.

ii. Factory warehouse or house used as a shop.

iii. Dwelling house.

iv. Cattle, pets, poultry, which are under one year old.

v. Clothes.

vi. Books and Magazines.

vii. Household articles.

viii. Apparatus and equipment, comfortable goods.

ix. Weapons and ammunition.

X. Deciduous farming and grain seeds.

xi. Accrued and spent money within the calculated year.

Zakat is an important pillar among the five pillars of Islam. The rules of Zakat distribution are mentioned in the Qur'an. If anyone distributes Zakat outside this; it is not lawful. So, the Zakat distribution areas are ${ }^{13}$ -

i. The first is to give Zakat to a fakir who has nothing.

ii. Miskin, the one who does not have the resources to manage his livelihood, is also eligible to receive Zakat.

iii. Zakat can also be given to the person who does not perform any other acts.

iv. Zakat money can also be used to win the hearts of non-Muslims when needed.

v. If a person is a slave and can be freed from slavery through Zakat, then that person can also be given Zakat. 
vi. A rich person can also be given Zakat if the debt of the rich and wealthy person exceeds his wealth.

vii. If a person is abroad for the jihad of religion, then that person can also be given Zakat.

viii. If a person lacks money which traveling. Then he is instructed to be given Zakat.

To the Muslim community, Zakat on the one hand makes the rich aware of their responsibilities towards the backward, disabled and destitute in the society by restraining and controlling the greed, selfishness, and greed for wealth. On the other hand, it promotes the overall economic development of the society through proportional distribution and makes the helpless poor financially self-sufficient. It can be said that "Zakat is the first law in the world of social security system". ${ }^{14}$

The impact of Zakat on the poverty of poor Muslims in the state over the next five years, if the wealthy people who pay Zakat in the state pay Zakat according to the rules and objectives of Islam, through a hypothetical study over the next five years through research on Zakat and meetings with Muslims from all walks of life in West Bengal. How much it is clearly noticeable. Of the 2 crores 46 lakh 53 thousand Muslims in West Bengal, let's assume that about 20 percent or 49 lakh 30 thousand 600 people pay Zakat according to the provisions of Shariat, and about 50 percent or 1 crore 23 lakh 26 thousand 500 poor Muslims who receive Zakat. The remaining 30 percent or 73 lakh 95 thousand 900 Muslims are financially self-sufficient and middle class.

Every Muslim who pays Zakat has to pay Zakat in a fixed amount at a certain time of the year as per the provisions of Shariah. If this Zakat is evaluated with the aim of measuring, so the minimum seven and a half tolas of gold i.e. 87.48 grams of gold is the current market price, If the price of 1 gram of gold is worth $4482^{15}$, then 87.48 grams of gold will be worth $4482 * 87.48=392085 /-$. Thus, a Muslim minimum Zakat at the rate of $2.5 \%$ means such $(392085 * 25) /(100 * 10)=9802 /-$.

Depending on the prevailing social system, if a person from West Bengal was given two minimum Zakat i.e. $9802 * 2=19604 /$ - for eliminating his poverty through a small business, then besides the elimination of the poverty of that person, the social discrimination and the 
discrimination of the rich and poor also eliminated. The total number of Zakat paying people of this state is $20 \%$ i.e. 49 lakhs 30 thousand 600 . About $50 \%$ of the total numbers are poor or Zakat receiving people i.e. 1 crore 23 lakhs 26 thousand 500. As a result, 20\% of the population of these districts pays $4930600 * 9802=48329741200 /-$ as Zakat in a year. That is, in a year 48329741200/19604=2465300 poor Muslim people of the district can be financially self-reliant through Zakat. That is, if the 24 lakhs 65 thousand 300 Muslim people can be financially self-reliant by paying Zakat of 19604 a year, then the poverty of the society can be eradicated by making $2465300 * 5=12326500$ Muslim people self-reliant in five years.

Table.1: The role of Zakat in eliminating society's poverty over the next five years

\begin{tabular}{|c|c|c|c|}
\hline Year & Number of poor & $\begin{array}{c}\text { Zakat receiving } \\
\text { people's of a year }\end{array}$ & Rest are poor people \\
\hline 2021 & $1,23,26,500$ & $24,65,300$ & $98,61,200$ \\
\hline 2022 & $98,61,200$ & $24,65,300$ & $73,95,900$ \\
\hline 2023 & $73,95,900$ & $24,65,300$ & $49,30,600$ \\
\hline 2024 & $49,30,600$ & $24,65,300$ & $24,65,300$ \\
\hline 2025 & $24,65,300$ & $24,65,300$ & 0 \\
\hline
\end{tabular}

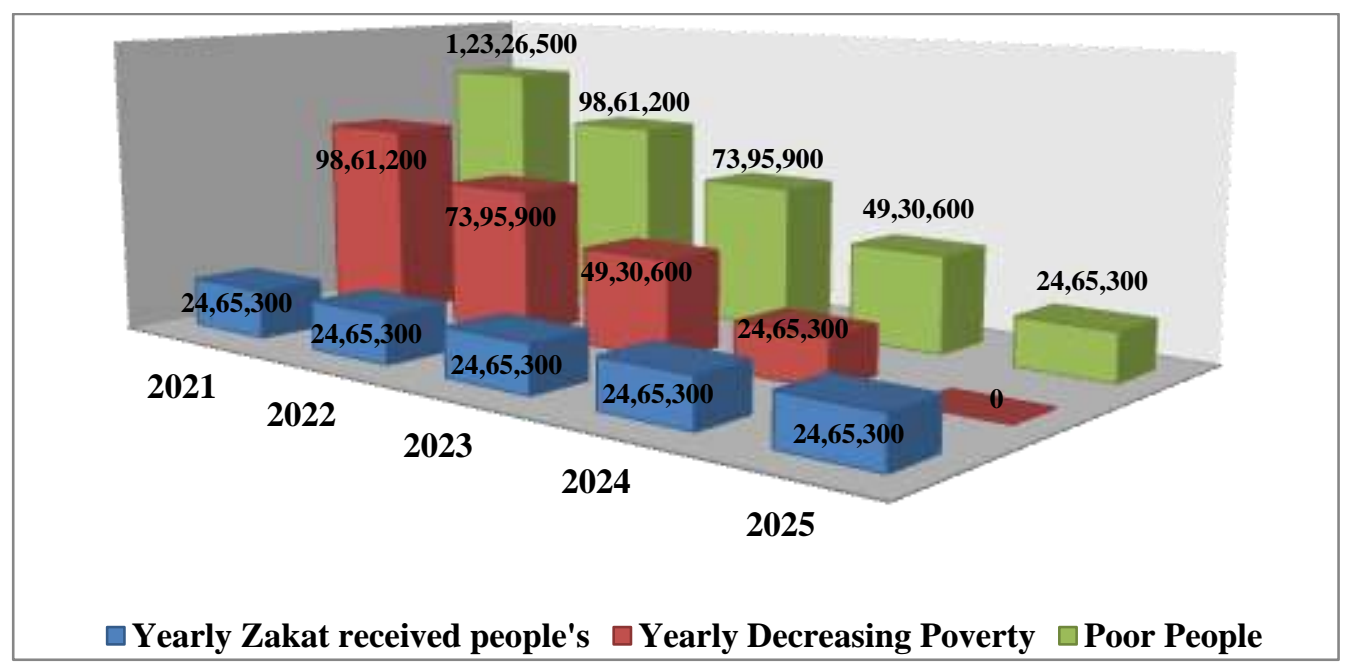

Figure.1: The role of Zakat in eliminating society's poverty over the next five years 
In some of the Islamic countries of the world, Zakat is a state law and the Muslim people of that country pay Zakat compulsorily. But since India has been a secular country, Zakat is only a religious observance to Muslims. As a result, the Muslim people of this state have their Zakat account or whether they are covered by paying Zakat! Evaluate everything yourself. Even some providers in the district pay Zakat in a way that does not serve the true purpose of paying Zakat in Islam. Also, about approx $85 \%$ of the 2 crores 46 lakhs 53 thousand Muslim people in the district i.e. 2 crores 9 lakhs 55 thousand 50 people do not know the real purpose of paying Zakat. The remaining 15\% i.e. approx 36 lakhs 97 thousand 950 Muslim people are aware of the true aims and objectives of Zakat.

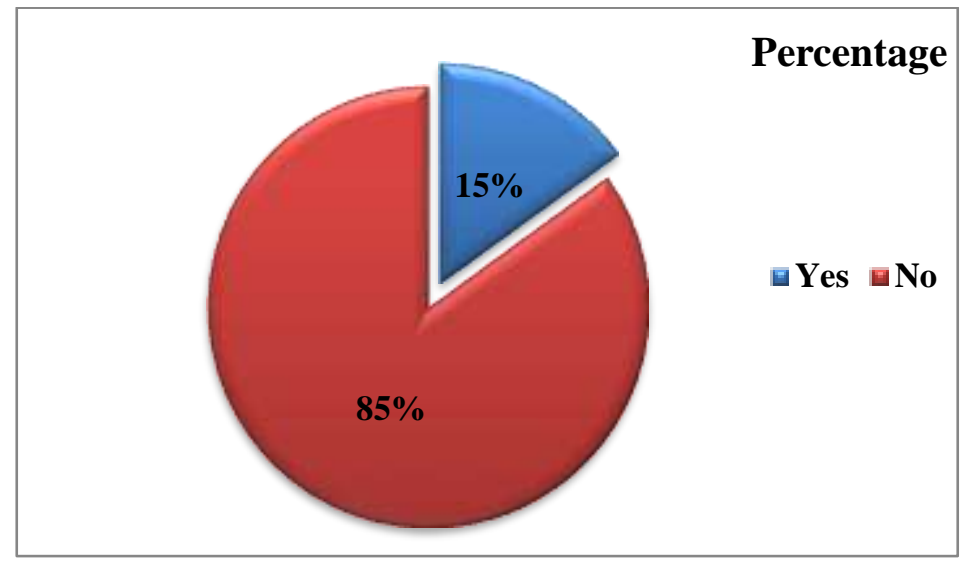

Figure.2: Status of serving the true purpose of paying Zakat

\section{Conclusion}

This study can be considered as the first attempt of Zakat analysis in assessing economic growth. Thus, it is clear that the recent plight of the Muslim people is due to the lack of empirical and theoretical information about Zakat. Research has shown that Zakat can predict economic growth as a measure and contribute to economic development in terms of poverty alleviation and reduction of unemployment. Although the results of this research paper are theoretical, research tests should be taken for future research. This article can contribute to the assessment of economic development as a new indicator for measuring the economic growth of the Muslim community in other states of India. On the other hand, in the current political and social situation, it will be possible to free the society from the influence of conservatism, superstition, and 
fundamentalism by making the youth aware of the complete social interpretation of the religious practice in order to preserve the religious existence and make the youth socially self-reliant.

\section{References:}

[1] Office of the Registrar General \& Census Commissioner, India. Ministry of Home Affairs, Government of India. https://www.census2011.co.in/census/state/west+bengal.html

[2] Franz von Benda-Beckmann, 'Social security between and future: Ambones networks of care and support', LIT Verlag, Munster, 2007, pp: 167, ISBN: 978-38258-0718-4.

[3] 'Al-Qur'an'. Surah: At-Tawba (9). Verse: 103.

[4] Maulana Hifzur Rahman, 'Economic System of Islam', translated by Maulana Abdul Awal, Dhaka, (1998), pp. 291.

[5] M.U.Ahmad, and A. Mahmood, 'Zakat fund-concept and perspective', Int. J. Monetary Economics and Finance, (2009), Vol. 2, Nos. 3/4, pp.197-205.

[6] Yusuf Karadai, 'Rule of Islamic Zakat' (first part). Translation: Maulana Mohammad Abdul Rahim,. Dhaka, pp: 42.

[7] M. A. Hamid, 'Islamic Economics', Rajshahi University, Rajshahi, (1999), pp. 222.

[8] Islamic Economics, pp. 96.

[9] M. Z. Hossain, 'Zakat in Islam: A Powerful Poverty Alleviating Instrument for Islamic Countries', International Journal of Economic Development Research and Investment, April( 2012). Vol. 3, No.1.

[10] Nisab and Distribution. Bangladesh Islamic Foundation, October 26, (2015).

[11] Md. Abu Sina, Khandakar Ziaul Haque, 'Zakat: Balancing is one of the components of life formation', The University studies, Kushtia, December (1997), Vol-6, pp.135-138.

[12] 'What is Zakat and why', Prof. Muhammad Sharif Hussein; Islamic bank foundation, (1995).

[13] Mohamed M.A.Salih, (Editor: Alexander De Waal), 'Islamism and its enemies in the Horn of Africa'. Indiana University Press, (2004), pp. 148-149. ISBN: 978-0253-34403-8.

[14] Qur'an, Surah: At-Tawba, Verse: 35:36.

[15] Gold Rate (March 11, 2020), Gold Price in India, Bank bazaar. https://www.bankbazaar.com/gold-rate-india.html 